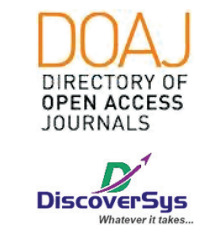

Published by DiscoverSys

\section{Efek penutupan Diastema menggunakan Silicone Guide dengan Komposit Nanofiller: Laporan Kasus}

\author{
Rudy Djuanda, ${ }^{1 *}$ Fadli Azhari ${ }^{2}$
}

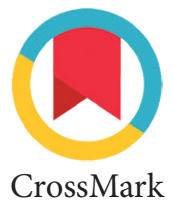

CrossMark

\title{
ABSTRACT
}

Background: Midline diastema is an aesthetic problem that can occur in anterior teeth where the closure of it can be performed by direct composite restorations. This study aims to see the benefits of using silicone guides and nanofiller composite resins to provide a smooth and esthetic restoration surface effect on the diastema closure.

Case Description: A 24-year-old woman came to the clinic with complaints of a gap in the front teeth which was considered to be very disturbing appearance. Patients had a desired to fix their teeth due to uncomfortable feeling when smiling. Clinically, there was a diastema between the teeth 11 and 21 . There was no caries found and teeth were found to be vital. While other teeth had a normal shape and there was no gap between the teeth. The gingival tissues around the tooth look normal and good oral hygiene and there was no low frenulum. Diastema closure using nanofiller composite restorations showed a good prognosis.

Conclusion: Midline diastema closure using silicone guide can provide precise results according to the analysis, either on the anatomy of the palatal, labial and dental midline. The use of nanofiller composite resins at the closure of midline diastemic can provide advantages of both strength and maximum polishing results.
'Departemen Konservasi Gigi, Fakultas Kedokteran Gigi Universitas Kristen Maranatha, Bandung

${ }^{2}$ Dokter Gigi Rumah Sakit Gigi dan Mulut Maranatha, Fakultas Kedokteran Gigi Universitas Kristen Maranatha, Bandung

\section{*Korespondensi:}

Rudy Djuanda, Departemen

Konservasi Gigi, Fakultas Kedokteran Gigi Universitas Kristen Maranatha, Bandung; JL. Prof. drg. Surya Sumantri, M.P.H. No. 65, Bandung; Kode Pos: 40164;

Telepon: +62 22-201 2186/ 2003450; rudy_djuanda@yahoo.com

Diterima: 2018-05-19 Disetujui: 2018-07-5 Diterbitkan: 2018-08-1

Keywords: Diastema, Silicon guide, Nanofiller

Cite This Article: Djuanda, R., Azhari, F. 2018. Efek penutupan Diastema menggunakan Silicone Guide dengan Komposit Nanofiller: Laporan Kasus. Intisari Sains Medis 9(2): 168-171. D0l: 10.1556/ism.v9i2.270

\section{ABSTRAK}

Pendahuluan. Diastema sentralis merupakan masalah estetik yang dapat terjadi pada gigi anterior dimana penutupan diastema sentralis dapat dilakukan dengan restorasi komposit direk. Penelitian ini bertujuan melihat manfaat penggunaan silicone guide dan resin komposit nanofiller dalam memberikan efek permukaan restorasi yang halus dan estetik pada penutupan diastema.

Deskripsi Kasus: Seorang perempuan berumur 24 tahun datang ke klinik dengan keluhan adanya celah di gigi depan yang dinilai sangat mengganggu penampilan. Pasien ingin memperbaiki giginya karena merasa tidak nyaman ketika tersenyum. Secara klinis terlihat adanya diastema diantara gigi 11 dan 21. Tidak ditemukan adanya karies dan gigi masih vital. Sementara gigi lain mempunyai bentuk yang normal dan tidak terdapat adanya celah antar gigi. Jaringan gingiva disekitar gigi terlihat normal dan kebersihan mulut baik serta tidak terdapat frenulum yang rendah. Penutupan diastema menggunakan restorasi komposit nanofiller menunjukkan prognosis yang baik.

Kesimpulan. Penutupan diastema sentralis menggunakan silicone guide dapat memberikan hasil yang presisi sesuai dengan analisis, baik pada anatomi palatal, labial, serta midline gigi. Penggunaan resin komposit nanofiller pada penutupan diastema sentralis dapat memberikan keuntungan baik dari kekuatan maupun hasil poles yang maksimal.

Kata kunci : Diastema, Silicon guide, Nanofiller

Cite Pasal Ini: Djuanda, R., Azhari, F. 2018. Efek penutupan Diastema menggunakan Silicone Guide dengan Komposit Nanofiller: Laporan Kasus. Intisari Sains Medis 9(2): 168-171. D0l: 10.1556/ism.v9i2.270

\section{PENDAHULUAN}

Diastema sentralis rahang atas merupakan suatu maloklusi yang sering muncul dengan ciri khas yaitu berupa celah yang terdapat diantara insisif sentralis rahang atas. ${ }^{1}$ Seringkali diastema ini menyebabkan gangguan estetik bagi sebagian orang, terutama diastema yang terdapat di anterior, sementara bagi sebagian orang, diastema ini dianggap sebagai suatu ciri khas dari orang tersebut dan bukan merupakan gangguan bagi penampilan estetiknya. Oleh karena bagi sebagian orang diastema sentralis ini merupakan suatu gangguan estetik terhadap penampilannya, maka banyak orang yang mencari dan meminta pertolongan dari dokter gigi untuk mengkoreksi kelainan tersebut. ${ }^{1,2}$

Salah satu teknik restorasi yang sangat sukses dan paling konservatif adalah penutupan dengan menggunakan bahan restorasi komposit, karena dengan prosedur ini diastema dapat tertutup tanpa 


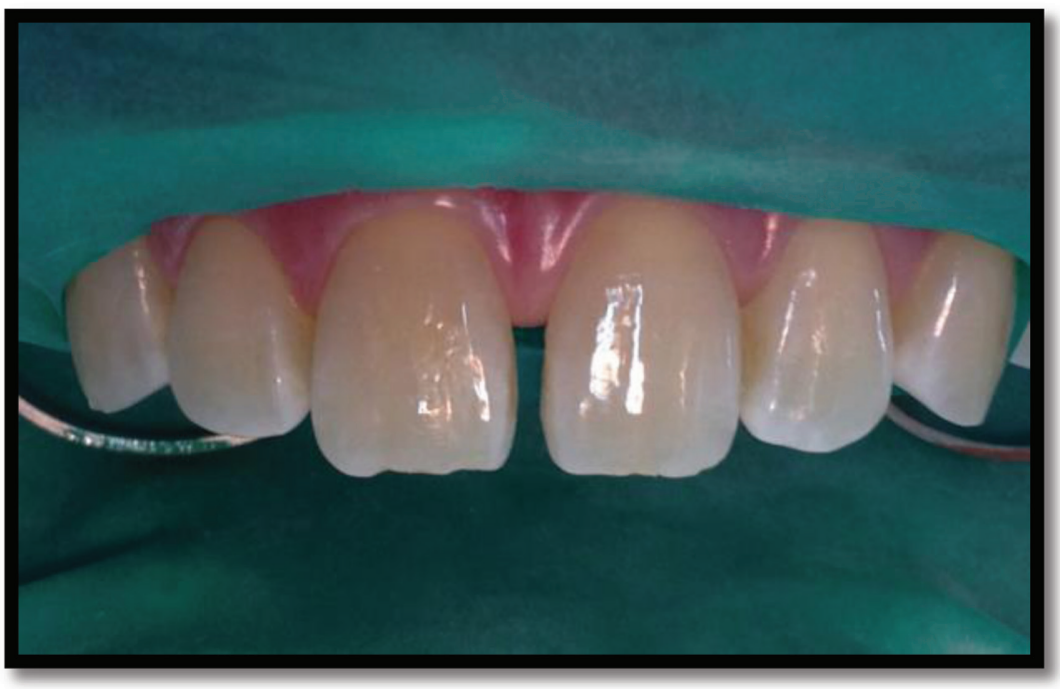

Gambar 1 Foto klinis gigi 11 dan 21

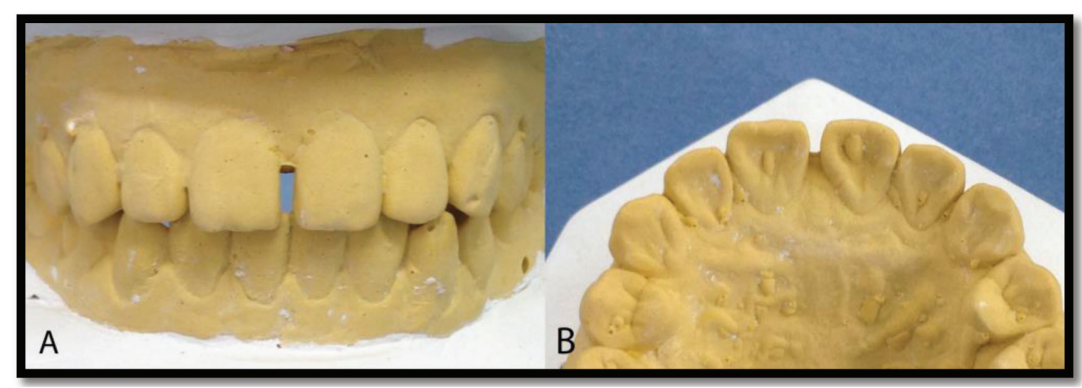

Gambar 2 Model kerja. (A) Tampak labial (B) Tampak palatal

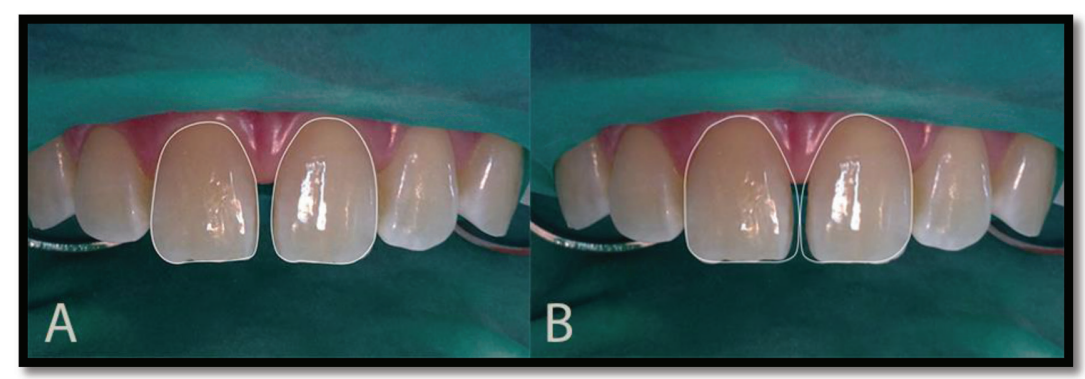

Gambar 3 Analisis perhitungan proporsi gigi 11 dan 21 (A) Outline awal (B) Outline rencana perawatan

merusak struktur gigi yang ada. ${ }^{2}$ Untuk mencapai kesuksesan estetik diperlukan sebuah media komunikasi antara dokter gigi dan pasien. Silicon guide dapat menjadi sebuah alat untuk mensukseskan perawatan setelah pembuatan diagnostik mock-up. ${ }^{3}$ Penggunaan silicon guide direkomendasikan untuk pembuatan anatomi palatal, perbaikan insisal yang fraktur, dan menutup diastema pada gigi anterior. ${ }^{4}$

Penutupan diastema menggunakan resin komposit direk merupakan tindakan yang paling invasif. Perkembangan bahan komposit memungkin dokter gigi dalam mencapai hasil estetik yang memuaskan. Komposit nanofiller dengan teknologi nano memungkinkan menghasilkan restorasi dengan permukaan yang halus serta kekuatan yang tinggi. ${ }^{5}$ Studi ini bertujuan untuk mengetahui manfaat penutupan diastema menggunakan Silicone Guide dengan komposit nanofiller. Kasus

Seorang perempuan berumur 24 tahun datang ke klinik dengan keluhan adanya celah pada gigi depan yang dinilai sangat mengganggu penampilan. Pasien ingin memperbaiki tampilan giginya karena merasa tidak nyaman ketika tersenyum. Secara klinis terlihat adanya diastema diantara gigi 11 dan 21. Tidak ditemukan adanya karies dan gigi masih vital. Sementara gigi lain mempunyai bentuk yang normal dan tidak terdapat adanya celah antar gigi. Jaringan gingiva disekitar gigi terlihat normal dan kebersihan mulut baik serta tidak terdapat frenulum yang rendah (Gambar 1).

Diagnosis gigi 11 dan 21 adalah gigi vital disertai diastema sentralis. Rencana perawatan yang akan dilakukan adalah penutupan diastema sentralis menggunakan silicone guide dengan komposit nanofiller. Prognosis perawatan baik.

Pada kunjungan pertama dilakukan anamnesis dan pemeriksaan klinis. Pasien setuju untuk dilakukan perbaikan bentuk dan proporsi gigi 11 dan 21 dengan warna yang sesuai dan dilanjutkan dengan pembuatan informed consent. Pemilihan warna gigi didapat warna A3.5 3M. Gigi dicetak dengan menggunakan bahan cetak polyvinylsiloxane dengan teknik double impression dan kemudian dicor dengan dental stone tipe IV untuk pembuatan model kerja (Gambar 2).

Model kerja dianalisis sesuai dengan proporsi gigi. Analisis dilakukan dengan cara mengukur lebar mesio distal gigi 11 dan 21 dengan menggunakan jangka sorong digital. Lebar ruangan 11 dan 21 adalah $19 \mathrm{~mm}$. Lebar gigi 11 dan 21 adalah 9 $\mathrm{mm}$, sedangkan celah antara gigi 11 dan 21 adalah $1 \mathrm{~mm}$ (Gambar 3).

Setelah didapat analisis perhitungan proporsi gigi, dilanjutkan dengan melakukan analisis secara digital sebagai media komunikasi kepada pasien mengenai rencana tahapan perawatan yang akan dilakukan (Gambar 3). Mock up dibuat pada model kerja sesuai dengan analisis yang dilakukan secara digital sehingga didapat bentuk proporsi yang ideal.

Silicone guide dibuat dengan menggunakan bahan cetak polivinylsiloxane dan dicetak pada model kerja yang sudah dibuat mock up. Bagian labial dipotong dengan blade nomor \#12 untuk mendapatkan cetakan bagian palatal

Pada kunjungan kedua, silicone guide yang telah dibuat kemudian di try-in pada gigi pasien. Gigi diisolasi dengan menggunakan rubber dam untuk mencegah kontaminasi saliva dan tetap dapat menjaga kelembaban gigi. Prosedur penutupan diastema dilakukan dengan resin komposit nanofiller Filtek Z350 (3M ESPE) (Gambar 4). 


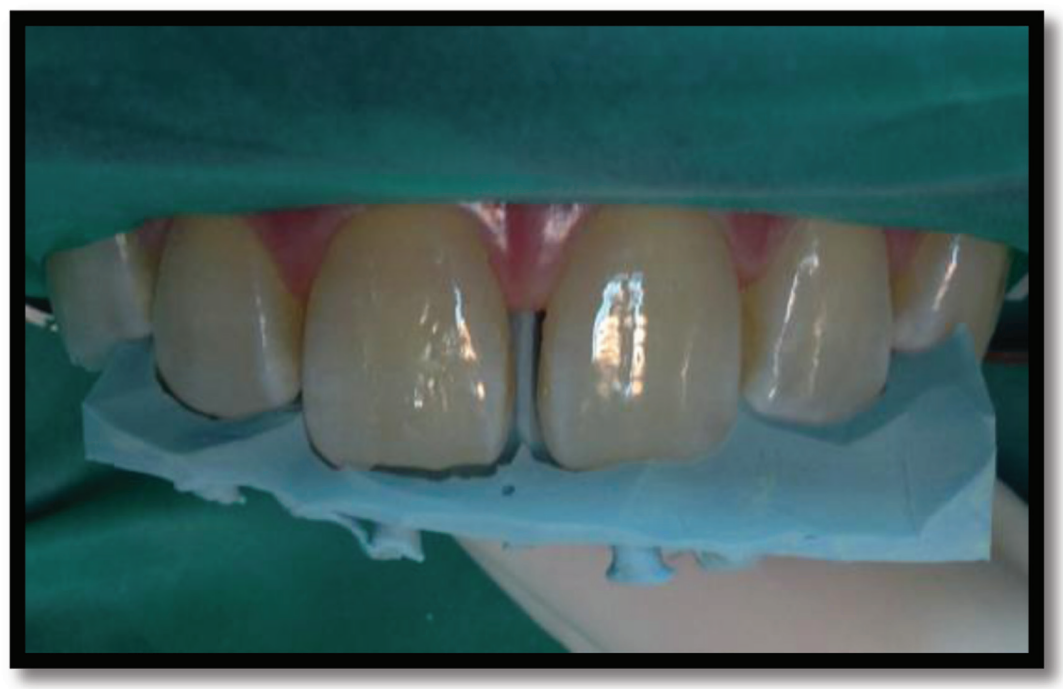

Gambar 4 Proses try-in pada gigi menggunakan Silicone guide

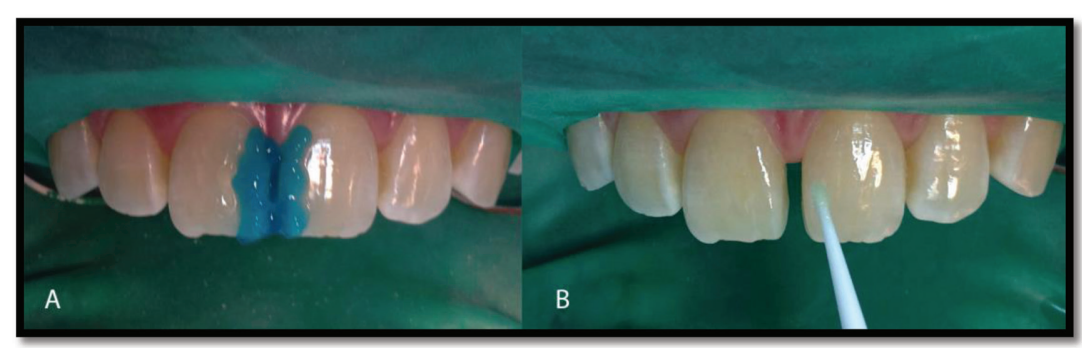

Gambar 5 (A) Aplikasi bahan etsa (B) Aplikasi bahan bonding

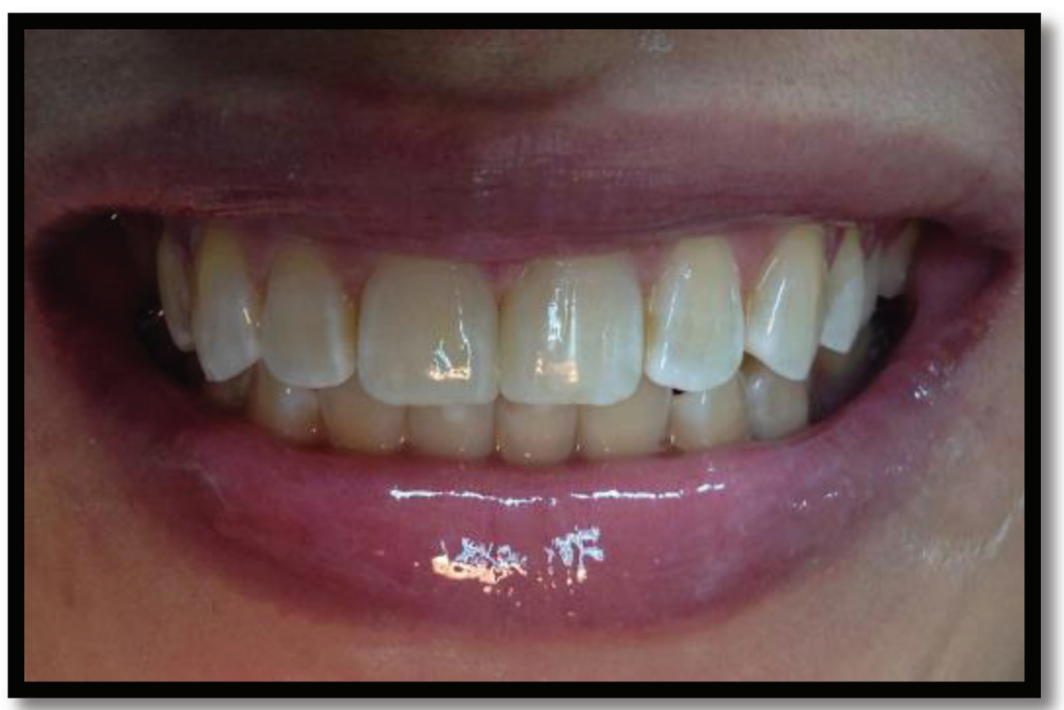

Gambar 6 Restorasi setelah pemolesan dan rubber dam dilepaskan

Penambalan dimulai dengan mengasarkan permukaan enamel gigi 11 dan 21 pada daerah mesial dengan menggunakan disc contouring. Asam fosfor $37 \%$ diaplikasikan pada bagian proksimal mesial gigi 11 dan 21 selama 20 detik dan kemudian dibilas dengan air. Bahan adesif diaplikasikan tipis pada bagian proksimal mesial gigi 11 dan 21 dan disemprot dengan angin sampai merata, kemudian di light cure selama 20 detik (Gambar 5).

Silicone guide dipasang pada gigi untuk menentukan midline sesuai dengan rencana perawatan pada model kerja. Resin komposit flow diaplikasikan ke silicon guide pada daerah proksimal gigi 11 sambil tetap mempertahankan agar tidak melewati midline, kemudian di light cure selama 20 detik. Perlakuan yang sama juga diaplikasikan pada gigi 21. Setelah terbentuk lapisan komposit sebelah palatal, kemudian diaplikasikan resin komposit Z350 secara inkremental sampai mencapai bentuk anatomis yang sesuai dengan rencana perawatan.

Finishing dilakukan menggunakan bur finishing disc dengan kecepatan rendah untuk menghaluskan permukaan labial dari restorasi. Pada bagian interdental gigi 11 dan 21 dilakukan polishing dengan menggunakan polish strip dilanjutkan pada bagian labial menggunakan bahan aluminum oxyde untuk memberikan tampilan yang mengkilat (Gambar 6).

Kontrol dilakukan pada kunjungan ketiga. Pemeriksaan subyektif tidak ada keluhan. Pemeriksaan objektif, adaptasi restorasi baik, tidak ada perubahan warna, tidak ada kontak prematur, gigi berfungsi dengan baik dan pasien merasa sangat puas.

\section{DISKUSI}

Diastema sentralis merupakan salah satu masalah estetik khususnya pada gigi anterior. Penyebab terjadinya diastema diantaranya, yaitu frenulum labial yang rendah sehingga menghambat pergeseran gigi insisivus sentralis untuk mendekat pada saat erupsi, tidak adanya benih gigi, ukuran gigi yang lebih kecil, dan ketidakcocokan antara ukuran gigi dengan ruang yang tersedia. Pada kasus ini penyebab diastema adalah frenulum labial yang rendah dan telah dilakukan pembedahan frenektomi 1 tahun sebelumnya. ${ }^{1,2}$

Penutupan diastema sentralis dapat dilakukan dengan beberapa teknik yaitu secara ortodontik, restorasi direk komposit, restorasi indirek ataupun kombinasi. Rencana perawatan diastema sentralis harus memperhatikan proporsi dari gigi anterior sesuai dengan golden proportion. Proporsi gigi insisivus pada kasus ini tidak melebihi $80 \%$ dari panjang gigi. Rencana perawatan yang dipilih pada kasus ini adalah penutupan diastema dengan restorasi direk menggunakan resin komposit. ${ }^{1,2,6,7}$

Restorasi direk komposit merupakan perawatan yang paling konservatif, kunjungan ke dokter gigi lebih sedikit dan tidak memerlukan tindakan ke laboratorium. Sebelum melakukan prosedur restorasi, terlebih dahulu dilakukan pembuatan 
mock up dengan menggunakan wax. Pembuatan mock up bertujuan untuk memberikan gambaran hasil akhir dari restorasi sehingga pasien dapat mengerti mengenai rencana perawatan yang akan dilakukan. ${ }^{3,8}$

Silicon guide dibuat menggunakan bahan cetak polyvinylsiloxane. Silicone guide akan mentransfer hasil mock up untuk digunakan pada saat restorasi. Penggunaan silicone guide sangat berguna pada kasus penutupan diastema sentralis. Penentuan batas median line serta margin proksimal akan sangat mudah ditentukan sehingga akan menghasilkan bentuk restorasi yang ideal.,9

Pada kasus ini digunakan resin komposit nanofiller Filtek Z350 (3M ESPE) yang akan menghasilkan bahan berkekuatan tinggi dan memiliki efek translusensi sehingga dapat menyerupai warna gigi. ${ }^{5,7}$

Untuk mendapatkan hasil restorasi yang maksimal diperlukan tindakan finishing dan polishing. Tahapan finishing bertujuan untuk membentuk kontur sesuai dengan bentuk akhir. Pada tahap ini masih meninggalkan permukaan restorasi yang masih kasar sehingga memerlukan tahapan polishing untuk mendapatkan permukaan yang halus dan hasil estetik yang maksimal. ${ }^{2,7,10,11}$ Pada akhirnya penggunaan silicone guide dengan komposit nanofiller memberikan hasil prognosis yang baik.

\section{SIMPULAN}

Penggunaan resin komposit nanofiller menggunakan silicone guide pada penutupan diastema sentralis dapat memberikan manfaat baik dari kekuatan maupun hasil poles yang maksimal. Penggunaan resin komposit dual shade dapat dijadikan pilihan pada kasus diastema yang cukup lebar.

\section{DAFTAR PUSTAKA}

1. Roberson TM, Heyman HI SE. Sturdevant's Art \& Science of Operatif Dentistry. $4^{\text {th }}$ ed. London: Mosby; 2002.

2. Albers HF. Tooth-Colored Restoratives. $9^{\text {th }}$ ed. London: BC Decker Inc; 2004.

3. St-pierre AL. Enhancement of Aesthetic Treatment Planning and Communication Using A Diagnosctic Mock-Up. Cosmetic Dentistry. 2012; 1-5

4. Cunha L, Valeretto TM, Pirolo R, Mondelli J, Gonzaga CC, Furuse AY. Free-hand Stratification With Composite Resins for The Closure of Anterior Diastema. RSBO. 2012 ; 9(3):334-9

5. Vargas M. A Step by Step Approach to A Diastema Closure. J Cosmet Dent. 2010;26(3).

6. Freedman G. Contemporary Esthetic Dentistry. USA: Elsevier Mosby; 2012.

7. Kim Y-H, Cho Y. Diastema Closure with Direct Composite. JKACD. 2011;36(6):515-9.

8. Kina S, Kataoka S. Achieving Aesthetic Diastema Closure. Int Dent. 2009;11(4):52-6.

9. Blank JT. Esthetic Anterior Composite Restorations. PennWell. 2011;2-12.

10. Mopper KW. Contouring, Finishing, and Polishing Anterior Composites. Inside Dentistry. 2011;62-70.

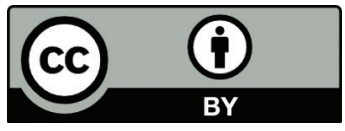

This work is licensed under a Creative Commons Attribution 